\title{
Osteosarcopenic obesity in women: impact, prevalence, and management challenges
}

\author{
This article was published in the following Dove Press journal: \\ International Journal of Women's Health \\ 13 January 2017 \\ Number of times this article has been viewed
}

\author{
Pegah JafariNasabian' \\ Julia E Inglis' \\ Owen J Kelly ${ }^{2}$ \\ Jasminka Z Ilich' \\ 'Department of Nutrition, Food \\ and Exercise Sciences, Florida State \\ University, Tallahassee, FL, ${ }^{2} \mathrm{Abbott}$ \\ Nutrition, Columbus, $\mathrm{OH}$, USA
}

\begin{abstract}
Osteosarcopenic obesity syndrome (OSO) has recently been identified as a condition encompassing osteopenia/osteoporosis, sarcopenia and obesity. OSO is especially deleterious in older adults (even if they are not obese by conventional measures), due to age-related redistribution of fat and its infiltration into bone and muscle. Osteoporosis and bone fractures in elderly increase the risk of sarcopenia, which, through decreased mobility, increases the risk of more falls and fractures, creating a vicious cycle. Obesity plays a dual role: to a certain extent, it promotes bone and muscle gains through mechanical loading; in contrast, increased adiposity is also a source of pro-inflammatory cytokines and other endocrine factors that impair bone and muscle. As the elderly population increases, changes in lifestyle to delay the onset of OSO, or prevent OSO, are warranted. Among these changes, dietary patterns and physical activity modifications are the first ones to be implemented. The typical Western diet (and lifestyle) promotes several chronic diseases including OSO, by facilitating a pro-inflammatory state, largely via the imbalance in omega-6/omega-3 fatty acid ratio and low-fiber and high-processed food consumption. Nutritional modifications to prevent and/or alleviate the OSO syndrome include adequate intake of protein, calcium, magnesium and vitamin $\mathrm{D}$ and increasing consumptions of foods containing omega-3 polyunsaturated fatty acids and fiber. Certain types of physical activity, often decreased in overweight/obese women and in elderly, might preserve bone and muscle, as well as help in reducing body fat accrual and fat infiltration. Habitual daily activities and some alternative modes of exercise may be more appropriate for older adults and play a crucial role in preventing bone and muscle loss and maintaining optimal weight. In conclusion, older adults who suffer from OSO syndrome may benefit from combined efforts to improve diet and physical activity, and such recommendations should be fostered as part of public health programs.
\end{abstract}

Keywords: aging, bone health, nutrition, osteosarcopenic obesity, physical activity

\section{Introduction}

Osteosarcopenic obesity syndrome (OSO), a complex, whole-body condition related to aging and possibly to some other diseases, impacting body composition and mobility, has recently been identified and defined in older adults. ${ }^{1,2}$ OSO encompasses three conditions that reflect the impairment of body composition: 1) deterioration of bone health, manifested as osteopenia and/or osteoporosis; 2) decline in muscle strength and mass, manifested as sarcopenia; and 3) increased presence of fat (adipose) tissue or its ultimate redistribution and infiltration into muscle and bone. ${ }^{1}$ Therefore, the components of OSO include osteopenic obesity and sarcopenic obesity (Figure 1). It needs to be emphasized that "obesity" is not necessarily limited only to a clinical diagnosis of overweight/obesity but also to the redistribution of fat in muscle and bone, which is an ultimate consequence of aging. ${ }^{1,2}$ This redistribution of fat mass may not be detected by measuring weight or body mass index (BMI); therefore, body
Correspondence: Jasminka Z llich Department of Nutrition, Food and Exercise Sciences, Florida State University, 120 Convocation Way,

Tallahassee, FL 323II, USA

Tel +l 8506457177

Email jilichernst@fsu.edu
International Journal of Women's Health 2017:9 33-42

33

Dovepress f $y$ in $\mathbf{0}$

http://dx.doi.org/10.2147/IJWH.S106107 (c) (1) (-) 2017 jafariNasabian et al. This work is published and licensed by Dove Medical Press Limited. The full terms of this license are available at https://www.dovepress.com/terms.php (c) 1 By $\mathrm{NC}$ and incorporate the Creative Commons Attribution - Non Commercial (unported, v3.0) License (http:///creativecommons.org/licenses/by-nc/3.0/). By accessing the work you hereby accept the Terms. Non-commercial uses of the work are permitted without any further permission from Dove Medical Press Limited, provided the work is properly attributed. For permission for commercial use of this work, please see paragraphs 4.2 and 5 of our Terms (https://www.dovepress.com/terms.php). 


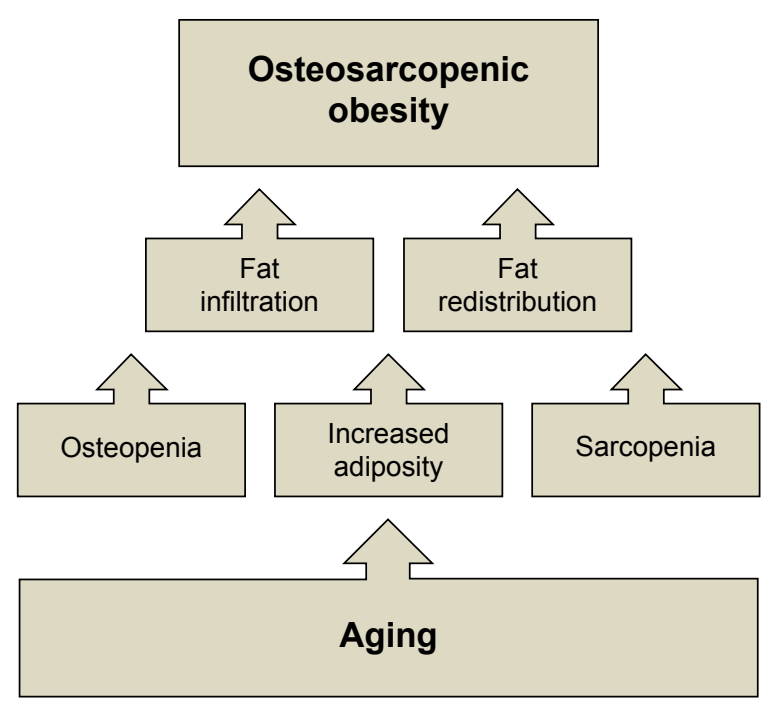

Figure I Changes in bone fat and muscle tissues with aging, leading to osteosarcopenic obesity.

Note: Adapted from Ageing Res Rev, 15, llich et al. Interrelationship among muscle, fat, and bone: connecting the dots on cellular, hormonal, and whole body levels, $51-60$, Copyright 2014, with permission from Elsevier.'

composition measurements might be more appropriate and useful in aging. OSO is also a result of the dysregulation of major metabolic pathways due to pro-inflammatory factors and endocrine imbalance, promoting the manifestation of osteoporosis, sarcopenia and increased adiposity, as well as low-grade chronic inflammation and insulin resistance. ${ }^{3,4}$ As the number of Americans over the age of 65 years surges, these diseases, separately or in combination, will become more prevalent. $^{5}$

Our objective was to give more insight into the OSO syndrome and its individual components. We present briefly the possible diagnostic criteria; ${ }^{2}$ still widely open for further modifications, as more knowledge is gained, and new technologies become available. We also address the impact of OSO on the overall health of individuals and society, provide some preliminary estimates of its prevalence and suggest some lifestyle measures, specifically nutrition and physical activity that might help in preventing or alleviating the OSO syndrome.

\section{Diagnostic criteria}

Some preliminary diagnostic criteria for OSO syndrome have been proposed recently. ${ }^{2}$ Since OSO syndrome is a complex condition, the criteria for its identification and diagnosis must include the combination of its individual components: osteoporosis/osteopenia and/or osteopenic obesity, sarcopenia and/or sarcopenic obesity and increased adiposity. The most accurate methods in diagnosing body composition parameters, such as bone mass, lean mass and body fat, include dual-energy X-ray absorptiometry (DXA) and the magnetic resonance imaging (MRI) techniques. ${ }^{6,7}$ To assess osteopenia/osteoporosis, a DXA scan gives the bone mineral density (BMD) and the "T-score" by regions of the body (eg, spine and femoral sites), allowing the clinician or researcher to diagnose the osteoporosis status and to estimate the patient's risk of bone fracture. ${ }^{6,7}$ However, it is also important to note that BMD presents only the proxy for the estimates of fracture risk. An important component of bone health is bone quality (bone turnover, geometry and microarchitecture), which cannot be measured directly or in vivo, and thus it is substituted by measuring BMD. ${ }^{8}$

The DXA scan also yields the analysis of lean and fat mass, both for total body and specific regions (eg, abdominal and appendicular). A number of researchers have used appendicular lean mass (arms and legs) to assess sarcopenia and sarcopenic obesity. ${ }^{9-11}$ The ability of DXA to also assess percent of total or regional body fat is useful in assessing the accumulation of fat in more dangerous regions such as the abdomen, as opposed to in the lower extremities such as the thighs and hips. ${ }^{7}$ The MRI technology provides much more precise measurements of muscle alone (rather than lean mass as with DXA), ${ }^{12}$ and it also goes a step further by allowing the researcher to assess the fat infiltration into bone marrow and muscle, enabling more adequate diagnosis of osteopenic obesity and/or sarcopenic obesity. ${ }^{13,14}$ However, this technology is very costly and rarely available for wider use.

Based on the abovementioned information, a recent analysis ${ }^{11}$ assessed bone loss via DXA measurements using a T-score of L1-L4 and/or total femur or femoral neck $<-1.0$; sarcopenia assessed via appendicular lean mass measured by DXA, and obesity based on percent body fat $(\geq 32 \%)$. ${ }^{15}$ Moreover, the combination of different serum biomarkers specific for each tissue, such as sclerostin, skeletal musclespecific troponin $\mathrm{T}$ (sTnT), leptin and adiponectin, could be used to further diagnose this syndrome. ${ }^{16}$ However, the first and easiest tests would be to conduct the physical performance assessment, including handgrip strength, one-leg stance, gait speed and sit-to-stand chair test, as proposed recently. ${ }^{2}$ Each of these measures has a specific cut off level for older women and men against which a certain impairment can be detected and a patient can then be referred for further evaluation to include analysis of serum biomarkers or body composition evaluation or both.

Despite the advanced technology, the precise detection of adipose tissue, either in the whole body or that infiltrated in bone marrow and muscle, still presents an obstacle for accurate assessment of body composition. Since adipose 
tissue has such a strong influence on bone and muscle, the following section gives more insight into those mechanisms.

\section{Effect of adiposity on bone and muscle}

Obesity and osteoporosis are still sometimes considered as mutually exclusive. Obesity (typically manifested as a higher weight) has been correlated with greater bone mass, bone strength and even bone quality over the life span, mostly as a result of increased mechanical loading. ${ }^{17,18}$ Mechanical loading stimulates bone formation by decreasing osteoblast apoptosis and also by increasing proliferation and differentiation of osteoblasts and osteocytes. ${ }^{19}$ In addition to providing added mechanical loading, obesity stimulates higher extraglandular estrogen ${ }^{20}$ and leptin secretion, both generally believed to preserve bone mass, decreasing susceptibility to fracture..$^{21}$

However, besides these metabolic and physiological changes, obese individuals may present with a higher risk of falls than nonobese adults and a subsequent higher fracture risk. Higher weight/fat tissue contributes to greater force in the course of a fall, possibly aggravating fracture risks and outcomes. ${ }^{18,19}$ While traditionally adipose tissue was considered primarily a site for energy storage, it is now regarded as an active endocrine organ involved in the secretion of many cytokines (adipokines), including tumor necrosis factor-alpha (TNF- $\alpha$ ), interleukin (IL) and C-reactive protein (CRP), ${ }^{3,22}$ as well as leptin and adiponectin. ${ }^{23}$ Excessive adiposity creates a type of pro-inflammatory state, which appears to favor fat accrual at the expense of bone and muscle and suppression of osteoblastogenesis and myogenesis. The hypothesized mechanism is that inflammation and increased systemic adipokine signaling force mesenchymal stem cells into the adipocyte lineage, resulting in higher adipogenesis, and declined osteoblastogenesis and myogenesis, ultimately resulting in fatty bones and muscle., ${ }^{1,24-26}$

The inflammatory cytokines TNF- $\alpha$ and IL-1 activate osteoclasts, while IL-6 (also known as bone-resorbing factor) stimulates osteoclastogenesis..$^{3,27,28}$ Leptin and adiponectin are both inflammatory modulating adipokines. ${ }^{23}$ Serum leptin is higher in overweight/obese individuals and promotes inflammation ${ }^{23,29}$ while adiponectin, the anti-inflammatory cytokine, is lower. ${ }^{23,30}$ These findings suggest that osteoclastogenesis and bone resorption are increased in response to increased inflammatory signals in obesity, second to a state of low-grade chronic inflammation, again perpetuated by obesity. ${ }^{3}$ In addition to acting on a cellular level, increased adiposity may also compromise both bone and muscle mass, strength and quality on a physiological level. ${ }^{31}$ There is an increased fat infiltration of bone and muscle in older adults, especially in the presence of obesity, which may further weaken and damage bone and muscle tissues. The relationship between obesity and osteoporosis, therefore, is a U-shaped curve, so that both underweight older adults and those with excessive body fat may be at risk. There appears to be a fine line at which adiposity stops being beneficial for bone and starts having adverse effects. In a cross-sectional study conducted in 471 healthy women in 2014, percent body fat higher than 33\% was negatively correlated with BMD of several skeletal sites. ${ }^{32}$ Although obesity has a role in malnutrition as a mediator of the effect on both osteoporosis and sarcopenia, ${ }^{33}$ it may not always be a protective factor against osteoporosis or sarcopenia, especially in older women. , $^{1,32,34}$

\section{Impact}

The increased risk of falls and fractures is probably the greatest concern for the osteosarcopenic obese population. ${ }^{11,35}$ Fall-related injuries are one of the major causes of mortality and morbidity among the elderly. These injuries could have a significant impact on health-related costs and quality of life. ${ }^{36}$ The cost of treating osteoporosis and subsequent bone fractures has been estimated to be $\$ 19$ billion annually. ${ }^{37}$ Aging accompanied by a sedentary lifestyle leads to muscle wasting, sarcopenia and reduced muscular strength, thereby impacting physical function and the ability to live independently. ${ }^{38}$ In 2014, one third of fall-related deaths were attributable to low BMD as well as muscle loss. ${ }^{36}$ The estimated economic costs associated with sarcopenia were $\$ 18.5$ billion in the US in 2000 . It is estimated that a mere $10 \%$ reduction in the prevalence of sarcopenia would reduce health care costs by $\sim \$ 1.1$ billion per year. ${ }^{39}$ Sarcopenia is associated with other complications prevalent in the elderly such as anorexia, frailty, osteoporosis, obesity and falls..$^{40,41}$

The economic impact of the third component of OSO, overweight/obesity, is especially manifested in health care costs and long-term loss of productivity. ${ }^{42,43}$ The annual medical cost for an obese individual is on average $\$ 1,429$ higher than that of a normal-weight healthy individual. The recent rise in the prevalence of obesity is associated with comorbidities such as type II diabetes mellitus, hypertension, hyperlipidemia, cardiovascular disease, stroke, asthma, obstructive sleep apnea, osteoarthritis, renal failure, cancer and others. ${ }^{44}$ Aside from all these complications, obesity has been associated with a 6-20-year decrease in life expectancy. ${ }^{45}$

While it is difficult to absolutely separate out single conditions/diseases, the impact of bone loss, muscle loss 
and excess adiposity, individually and combined, on comorbidities is clear. In addition, all are independently associated with significantly greater direct health care costs (insurance companies and government); however, the indirect (eg, work days lost, impact on family caregivers) impact of these conditions/diseases has not been evaluated. ${ }^{46,47}$ Thus, the combined condition of OSO could be associated with greater direct and indirect health care costs. Preventing and providing the appropriate treatment for OSO may reduce this economic burden and improve the quality of life of millions of people.

\section{Prevalence}

Currently, there are no estimates for the number/percentage of people suffering from the combined condition of the OSO syndrome, because the syndrome itself is a newly identified one and the diagnostic criteria are just being developed, as described earlier. ${ }^{1,2}$ However, the statistics on its components is available. For example, regarding the bone health, at least 54 million Americans currently have osteopenia and/or osteoporosis, and one in two American women will experience a bone fracture. ${ }^{37,48}$ Additionally, 5\%-13\% of adults $>65$ years old and $\sim 50 \%$ of adults $>80$ years old have sarcopenia. ${ }^{49,50}$ Ironically, hip or any other osteoporotic fracture accelerates the onset of sarcopenia in older adults; and sarcopenia, which impairs overall physical function, increases the risk of falls and fractures; ${ }^{11,49}$ thus, these two conditions feed perpetually into each other. Obesity, once believed to be protective of bone and muscle mass, is increasingly linked to deterioration in bone and muscle, especially with aging, 1,51,52 although, a recent study suggested the existence of OSO syndrome in a younger-age overweight adult, causing the changes in body composition similar to those seen in elderly populations. ${ }^{53}$

One component of OSO, the osteopenic obesity, ${ }^{1}$ a combined condition of bone loss and increased/redistributed body fat, may accelerate physical decline. Osteoblasts and adipocytes share common mesenchymal stem cell lineages. In the aged bone microenvironment where low-grade chronic inflammation persists, there is an increase in adipogenesis and suppression of osteoblastogenesis. ${ }^{1,24-26}$ In our previous analysis, osteopenic obese women had significantly lower physical performance (such as normal walking speed) than obese-only women (those without significant bone loss or muscle loss), suggesting that bone plays an important role in functional performance. ${ }^{11}$

Sarcopenic obesity, like osteopenic obesity, was once overlooked, due to the fact that overweight/obese individuals have greater overall mass, including muscle mass, thus it was believed that they were protected from age-related loss of muscle mass, strength and even mobility. ${ }^{51}$ However, new findings show that the greater amount of lean mass (as a result of overall greater body weight) may not be adequate for an overweight/obese older adult to maintain overall function. ${ }^{1,9,51}$ Sarcopenic obesity is the result of increased fat mass and fat infiltration into muscle, leading to lower muscle mass, quality and functionality and possibly increased frailty. ${ }^{11,54}$ However, increased percent body fat, especially when combined with decreased lean mass with age, is particularly deleterious for bone in women. ${ }^{52,54}$ Therefore, older adults with osteosarcopenic obesity have significantly higher risk of mobility deterioration, which is reflected in weaker grip strength, slower walking speed and poorer balance than older women presenting with obesity only, as shown recently. ${ }^{11,34}$ Impaired functional performance will lead to increased incidence for falls and subsequent fractures. Therefore, effective preventative measures to delay or even reverse OSO are highly warranted.

The increasing rise in obesity is well known, ${ }^{55-57}$ and it will not be discussed further in this review. However, an important point to note again is the age-related, or some other chronic condition-related, infiltration of fat into bone marrow and muscle, probably replacing the bone and muscle cells and impairing the function of each tissue. Therefore, it is important to focus not only on obesity as determined by conventional measures (BMI, percent of body fat) but also on the "hidden fat", although the latter one might not be easy to detect.

Regarding the prevalence of OSO, there are some estimates derived from a few preliminary studies. A post hoc analysis conducted in $\sim 500$ overweight/obese women across a wide age range revealed that $25 \%$ had osteosarcopenic obesity. ${ }^{58}$ However, another study conducted in overweight/obese postmenopausal women estimated that a more conservative $12 \%$ of the women could be diagnosed with OSO. ${ }^{11}$ Surprisingly, the osteosarcopenic obesity phenotype was recently identified in overweight/obese young (18-21 years) women and men. The study was conducted in over 2,500 people, and those who were overweight/obese showed unfavorable body composition and higher proinflammatory markers, compared to their normal-weight counterparts. ${ }^{53}$ A recent pilot study conducted in older women (ages $65+$ ) found $\sim 18 \%$ of participants presenting with OSO syndrome (unpublished data; doctoral dissertations in progress). ${ }^{16,59}$ In all these studies (except for one in younger population $^{53}$ ), sarcopenic obesity was identified by comparing 
appendicular lean mass with fat mass (measured by DXA) in a linear regression model, ${ }^{9}$ and osteopenia/osteoporosis was identified with T-scores $<-1$ for lumbar spine and/or total femur or femoral neck. ${ }^{60}$

\section{Management}

Although chronic diseases, drug therapy, genetic predisposition and environmental factors are the major determinants in the etiology of OSO, lifestyle factors such as dietary patterns and physical activity are important as well. The latter two play a substantial role in metabolic homeostasis, determining to what extent an individual is able to preserve bone mass, muscle mass and overall function, while still preserving an optimal body weight or reducing obesity with age..$^{61,62}$

\section{Nutrition}

Although American adults consume more food and total energy than people of many other cultures worldwide, evidence points to an increased malnutrition risk with age and a link between the so-called "Western diet" and development of some chronic diseases, including bone, muscle and fat tissue disorders. ${ }^{3}$ Some of the reasons why older adults in the US are potentially at nutritional risk include increased consumption of high-energy and low-nutrient dense types of food, inadequate dietary fiber consumption and decreased ability to absorb or utilize some essential nutrients. ${ }^{61-63}$ The Western diet being heavily based on processed food provides an increased amount of energy but decreased amount of many essential nutrients. Over time, this may promote the metabolic deregulation of major systems in the body, leading to bone loss, muscle loss and increased adiposity, as well as increased insulin resistance and low-grade chronic inflammation. ${ }^{3}$ A typically low dietary fiber intake in older Americans is associated with insulin resistance and increased inflammation, especially in the obese. ${ }^{64}$ The Western diet is also characterized by a high ratio of omega- 6 to omega- 3 polyunsaturated fatty acids, which contributes to low-grade chronic inflammation and other unfavorable physiological outcomes. ${ }^{3,61,62}$ Besides the relatively unwholesome diet, older adults also often consume less nutrients secondary to decreased appetite, side effects from medications, dementia or a desire for weight loss. Particularly affected nutrients are protein, calcium, magnesium and vitamin $\mathrm{D}$, all needed to maintain and build bone and muscle. ${ }^{65}$ Additionally, absorption and utilization of most vitamins and minerals are also decreased with aging. ${ }^{66}$ Table 1 depicts the nutritional recommendations for bone and muscle health and reduction/maintenance of body weight.
The important role of calcium and vitamin D in bone health has been thoroughly reported previously. Likewise, the intake of energy, protein and calcium has been shown to be independently related to BMD in several skeletal sites. ${ }^{67}$ Low-calcium diets could increase the circulating 1,25-dihydroxyvitamin D (calcitriol), which then stimulates adipogenesis via a specific-membrane vitamin D receptor. ${ }^{68}$ Insufficient energy, and especially protein intake, can also increase muscle wasting. ${ }^{69}$ Anorexia of aging and the change in gastrointestinal hormones deprive the skeletal muscles of amino acids required for protein synthesis, thereby causing protein degradation. ${ }^{69,70}$ The current recommended dietary allowance (RDA) for protein is $0.8 \mathrm{~g} / \mathrm{kg} / \mathrm{d}$ for adults. However, nitrogen balance studies suggest that older adults need to consume a higher amount of protein $(1.4-1.6 \mathrm{~g} / \mathrm{kg} / \mathrm{d}) .^{71-73} \mathrm{In}$ a recently published review, protein intake of $1.0-1.3 \mathrm{~g} / \mathrm{kg} / \mathrm{d}$ has been recommended to reduce muscle loss in elderly populations. ${ }^{74}$ Inadequate protein intake in aging adults combined with physical inactivity may further exacerbate the decline in muscle protein synthesis associated with aging. For example, in a 14-week study conducted in 2001, men and women aged $54-78$ years were provided with eucaloric diets of $0.8 \mathrm{~g} / \mathrm{kg}$ protein per day. A $21 \%$ reduction in nitrogen excretion was reported and was significantly correlated $(r=0.83)$ with a decrease in thigh muscle cross-sectional area. ${ }^{75}$ A negative nitrogen balance, with a simultaneous decrease in muscle mass, indicates compromised muscle protein synthesis in order to conserve total body protein (all in response to lower protein intake). These findings indicate that the RDA for protein $(0.8 \mathrm{~g} / \mathrm{kg} / \mathrm{d})$ may not be adequate for the maintenance of skeletal muscle in aging adults. However, it needs to be noted that with an adequate consumption of energy from fat and carbohydrate, less protein will be utilized for energy needs, and thus it will be spared..$^{49}$ A recent analysis of National Health and Nutrition Examination Survey (NHANES) data shows that energy imbalance, and lower protein intakes, in addition to excess of simple carbohydrates, and low long-chain polyunsaturated fatty acid intakes may contribute to OSO. ${ }^{61}$

Carbohydrate intake is controversial regarding bone health. A randomized control crossover trial showed that there is no significant difference in serum osteocalcin (marker of bone formation), carboxyl- (C-) terminal cross-linking telopeptides of type I collagen (marker of bone turnover), bone-specific alkaline phosphatase (marker of bone formation) and urinary ( $\mathrm{N}-$ ) terminal cross-linking telopeptides of type I collagen (marker of bone turnover) between a control and a low carbohydrate diet. ${ }^{76}$ Regarding polyunsaturated 
Table I Nutritional and physical activity recommendations for bone and muscle health and reduction/maintenance of body weight*

\begin{tabular}{|c|c|c|c|c|}
\hline $\begin{array}{l}\text { Affected } \\
\text { tissue }\end{array}$ & Condition & $\begin{array}{l}\text { Possible nutritional interventions/ } \\
\text { treatments }\end{array}$ & $\begin{array}{l}\text { Possible exercise interventions/ } \\
\text { treatments }\end{array}$ & $\begin{array}{l}\text { Underlying mechanism of } \\
\text { benefit }\end{array}$ \\
\hline Bone & $\begin{array}{l}\text { Osteopenia or } \\
\text { osteoporosis }\end{array}$ & $\begin{array}{l}\text { - Calcium (RDA for } \geq 5 \text { I years) - } \\
\text { I,200 mg/d } \\
\text { - Magnesium: meet RDA ( } 320 \mathrm{mg} / \mathrm{d} \\
\text { for women) }{ }^{102} \\
\text { - Vitamin D: } 800 \mathrm{lU} / \mathrm{d}^{103} \\
\text { - Vitamin D: serum level }>20 \mathrm{ng} / \mathrm{mL}^{103} \\
\text { - Protein }>\text { I g/kg/d } / \mathrm{d}^{72,73} \\
\text { - Omega-3 PUFA (especially } \\
\text { long chain EPA and DHA) - } \\
\text { at least I g/d EPA + DHA and }>\text { I g } \\
\text { ALA } 20,77\end{array}$ & $\begin{array}{l}\text { - Weight-bearing (resistance } \\
\text { exercise) physical activity } \\
2-3 \text { times/wk }{ }^{82,83} \\
\text { - Comprehensive exercise program } \\
\text { should include aerobic, strength, } \\
\text { flexibility and balance training } \\
\text { - Take preventive steps to reduce } \\
\text { risk of fall (balance training, tai chi, } \\
\text { yoga, etc.) } \\
\text { - Exercise according to ability - as } \\
\text { ability, the intensity of exercise can } \\
\text { increase }{ }^{104}\end{array}$ & $\begin{array}{l}\text { - Prevents bone loss by } \\
\text { reducing osteoclastogenesis } \\
\text { and adipogenesis and } \\
\text { increasing osteoblastogenesis } \\
\text { in the bone }{ }^{105} \\
\text { - Reduces inflammation }{ }^{106}\end{array}$ \\
\hline Muscle & Sarcopenia & $\begin{array}{l}\text { - Protein diet: } 1.4-1.6 \mathrm{~g} / \mathrm{kg} / \mathrm{d}^{74,107} \\
\text { - Vitamin D: } 800 \mathrm{IU} / \mathrm{d}^{103} \\
\text { - Vitamin D: serum level }>20 \mathrm{ng} / \mathrm{mL}^{103} \\
\text { - Omega-3 PUFA long } \\
\text { chain }>\mathrm{I} \mathrm{g} / \mathrm{d}^{62,77}\end{array}$ & $\begin{array}{l}\text { Weight-bearing physical activity } \\
2-3 \text { times/wk } \\
\text { - Exercise to match ability - as } \\
\text { ability improves intensity of } \\
\text { exercises can increase }{ }^{104}\end{array}$ & $\begin{array}{l}\text { - Increases muscle protein } \\
\text { synthesis } \\
\text { - Improves muscle function } \\
\text { - Reduces anabolic resistance } \\
\text { - Ro8 }\end{array}$ \\
\hline Adipose & $\begin{array}{l}\text { Overweight or } \\
\text { obesity }\end{array}$ & 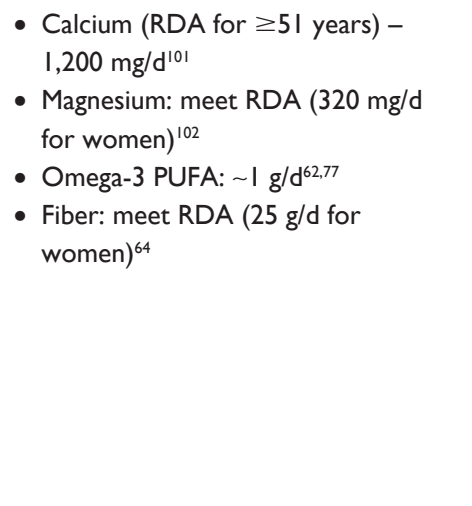 & $\begin{array}{l}\text { - } 300 \text { minutes moderate- } \\
\text { intensity exercise per week } \\
(60 \mathrm{~min} \times 5 \text { days/wk) to optimize } \\
\text { the impact of exercise on weight }{ }^{109} \\
\text { - Comprehensive exercise program } \\
\text { should include aerobic, strength, } \\
\text { flexibility and balance training }{ }^{82,83} \\
\text { - Improve balance to reduce risk of } \\
\text { fall (balance training, tai chi, yoga, } \\
\text { etc. })^{82,83} \\
\text { - Exercise to match ability - as } \\
\text { ability improves the intensity of } \\
\text { exercises can increase }{ }^{104}\end{array}$ & $\begin{array}{l}\text { - Improves weight loss and } \\
\text { maintenance } \\
\text { - Reduces risk of metabolic } \\
\text { syndrome } \\
\text { - Lowers cholesterol } \\
\text { - Reduces fat infiltration by } \\
\text { stimulating muscles to oxidize } \\
\text { interstitial fat" } \\
\text { - Reduces inflammation }\end{array}$ \\
\hline $\begin{array}{l}\text { Bone, muscle } \\
\text { and adipose } \\
\text { tissue }\end{array}$ & $\begin{array}{l}\text { Osteosarcopenic } \\
\text { obesity }\end{array}$ & $\begin{array}{l}\text { - Calcium: I,200 mg/d } \\
\text { - Magnesium: meet RDA ( } 320 \mathrm{mg} / \mathrm{d} \\
\text { for women) } \\
\text { - Vitamin D: } 800 \mathrm{IU} / \mathrm{d}^{103} \\
\text { - Vitamin D: serum level }>20 \mathrm{ng} / \mathrm{mL}^{103} \\
\text { - High protein diet: } 1.4-1.6 \mathrm{~g} / \mathrm{kg} / \mathrm{d} \\
\text { - Omega-3 PUFA (especially long- } \\
\text { chain EPA and DHA) - at least I g/d } \\
\text { EPA + DHA and >I g ALA } \\
\text { - Fiber: meet RDA ( } 25 \mathrm{~g} / \mathrm{d} \text { for } \\
\text { women) }{ }^{64}\end{array}$ & $\begin{array}{l}\text { - Comprehensive exercise program } \\
\text { should include aerobic, strength, } \\
\text { flexibility and balance training and } \\
300 \text { minutes moderate-intensity } \\
\text { exercise per week ( } 60 \text { min } \\
\times 5 \text { days/wk) to optimize the } \\
\text { impact of exercise on weight } \\
\text { - Weight-bearing physical activity } \\
2-3 \text { times/wk } \\
\text { - Exercise to match ability - as } \\
\text { ability improves the intensity of } \\
\text { exercises can increase }{ }^{104} \\
300 \text { minutes moderate- } \\
\text { intensity exercise per week } \\
\text { ( } 60 \text { min } \times 5 \text { days/wk) to optimize } \\
\text { the impact of exercise on weight }{ }^{109}\end{array}$ & $\begin{array}{l}\text { - Bone, muscle mass/quality } \\
\text { and adipose tissue are } \\
\text { interrelated. Bone loss } \\
\text { (osteoporosis or osteopenia) } \\
\text { can be accompanied with } \\
\text { an increase in the fat } \\
\text { mass (obesity) or fat's } \\
\text { infiltration into the bone and } \\
\text { similarly, sarcopenia can be } \\
\text { accompanied with increase in } \\
\text { infiltration of fat into muscle' }\end{array}$ \\
\hline
\end{tabular}

Notes: *The recommendations are given for each basic condition: osteoporosis, sarcopenia and overweight/obesity, from which osteopenic obesity and sarcopenic obesity could be extrapolated. The osteosarcopenic obesity contains the most comprehensive recommendations encompassing those for each condition.

Abbreviations: RDA, recommended dietary allowances; PUFA, polyunsaturated fatty acids; EPA, eicosapentaenoic acid; DHA, docosahexaenoic acid; ALA, alpha linolenic acid.

fatty acids, in addition to the beneficial effects of omega-3 fatty acids on numerous health outcomes, eicosapentaenoic acid (EPA) and docosahexaenoic acid (DHA), specifically, were shown to promote bone formation and reduce the negative effects of adiposity on bone. ${ }^{77}$ The combination of low protein, high simple carbohydrates, deficiencies of calcium, magnesium and potassium and excess of phosphorus, sodium and iron may be associated with lower bone mass, sarcopenia and obesity and, therefore, OSO syndrome. ${ }^{61,62}$ Overall, the nutrient composition of the Western diet, distribution and 
amounts, for both macro and micronutrients may not promote healthy aging and may be contributing to the development of OSO syndrome.

\section{Physical activity}

In general, physical activity is needed for maintenance and improvement of all components of body composition, as well as the physiological and mental health in people of all ages. ${ }^{78}$ Specifically for the OSO syndrome, physical activity, even in the form of low intensity or habitual activity, is needed to maintain or improve BMD, ${ }^{67,79,80}$ maintain muscle strength and quality, improve balance and reduce adiposity and inflammation, with aging. ${ }^{80,81}$ Different studies have revealed that the rate at which BMD is lost can be slowed by weight-bearing physical activity, even in old age. ${ }^{82,83}$ Therefore, specific means of physical activity have been prescribed for the prevention and treatment of osteoporosis and overall bone health. A comprehensive exercise program for older adults should include aerobic, strength, flexibility and balance training. ${ }^{84}$ All the four components are crucial for the maintenance of body composition and healthy aging. A comprehensive exercise program serves to reduce the risk of falls, increase functional ability and improve the quality of life among older individuals. ${ }^{85,86}$ Table 1 lists the recommendations of physical activity modes for bone and muscle health and reduction/maintenance of body weight.

With society's emphasis on weight loss, studies have shown that weight loss also results in the reduction of both bone and muscle mass, which is relevant for postmenopausal women. Several studies have shown decreased BMD in overweight or obese women both during and after weight loss. ${ }^{87-91}$ Either intentional or unintentional weight loss is accompanied by bone loss and thus can raise the risk of fractures in older women..$^{23,90}$ It has been shown that diet-induced weight loss reduced bone mass due to decreased mechanical loading on the skeleton. ${ }^{92}$ Regarding preservation of lean mass (muscle), recent findings show that resistance exercise increases lean mass most effectively, but the best exercise for older adults is what they are able to do, as reviewed recently. ${ }^{80}$ Besides improving bone remodeling, mechanical loading can also positively affect myogenesis. Strength training has been shown to inhibit muscle protein breakdown and may help to maintain and increase muscle mass. ${ }^{93,94}$ Reducing adiposity through both aerobic and strength training is substantial in attenuating the inflammatory environment and thereby reducing bone and muscle loss and inhibiting the progression of OSO syndrome. ${ }^{95,96}$
It is important to consider that physical activity or exercise in middle-aged to older adults may be more beneficial for reducing the rate of bone or muscle loss rather than a significant increase in each. ${ }^{97}$ Exercise programs that have included brisk walking, stair climbing and descending, jogging, rowing and weight lifting can be effective in attenuating bone loss in older women. ${ }^{97,98}$ Aside from some medium to high-impact activities, habitual and low-impact physical activities including heavy housework, gardening, do-it-yourself activities, recreational activities and walking have been shown to be beneficial for bone in postmenopausal women. ${ }^{67}$ Any period of immobility and immobilization should be avoided as much as possible among elderly. When an individual is sick or injured, even brief daily walking or any type of weight-bearing movements may help to protect BMD and muscle functioning. Other alternative exercises such as tai chi, yoga and pilates, as well as whole body vibration, could be used to support favorable body composition and prevent bone loss. It has also been shown that these types of exercise are associated with an increase in quality of life of older individuals. ${ }^{80}$ Overall, older adults may require special considerations such as tailoring progression of exercise intensity and beginning at a lower intensity. Furthermore, the low-impact physical activity and alternative exercises should be the focus for older individuals and those with higher risk of fall and injuries. ${ }^{99,100}$

\section{Conclusion}

OSO syndrome is a multifactorial condition of age-related changes in body composition including bone and muscle loss combined with increased or redistributed adiposity. This complex condition is not caused by one single component, but by an amalgamation of elements, such as poor nutrition, lack of physical activity, low-grade chronic inflammation, and aggravated in the milieu of some chronic diseases, as well as the metabolic consequences of all these factors over time. Treatment for the OSO syndrome or its management requires the combination of healthy/optimal nutrition and exercise training or different modes of physical activity to attenuate the progression or even to prevent it (Table 1). For the best prevention, efforts should be made to achieve peak bone mass before the age of 30 years, gain/maintain muscle mass at all ages and maintain a healthy body weight. In addition, due to its complex etiology and treatment requirements, body composition measures may be helpful. As discussed in this review, nutritional modifications to prevent and/or alleviate the OSO syndrome include adequate protein, fiber and energy intake, adequate calcium, magnesium and 
vitamin $\mathrm{D}$ and consumptions of food containing omega-3 polyunsaturated fatty acids (flaxseed oil, fish oil, walnuts and soybeans), the latter to avoid low-grade chronic inflammation. Equally important would be the treatment of the age-related anorexia and diminished absorption and utilization of vitamins and minerals. In addition, physical activity, including strength training and aerobic exercise, supports the maintenance of bone mass and skeletal muscle and thus attenuates osteopenia/osteoporosis as well as sarcopenia. Both aerobic exercise and strength training stimulate lipolysis, and thereby contribute to the reduction of obesity. As discussed in this review, habitual daily activity and some alternative modes of exercise may be more appropriate for older adults and thus play a crucial role in preventing bone and muscle loss and maintaining optimal weight. In conclusion, nutritional interventions, in combination with physical activity and exercise training, are essential for the prevention and management of OSO syndrome.

\section{Disclosure}

The authors report no conflicts of interest in this work.

\section{References}

1. Ilich JZ, Kelly OJ, Inglis JE, Panton LB, Duque G, Ormsbee MJ. Interrelationship among muscle, fat, and bone: connecting the dots on cellular, hormonal, and whole body levels. Ageing Res Rev. 2014;15:51-60.

2. Ilich JZ, Kelly OJ, Inglis JE. Osteosarcopenic obesity syndrome: what is it and how can it be identified and diagnosed? Curr Gerontol Geriatr Res. 2016;2016:1-7.

3. Ilich JZ, Kelly OJ, Kim Y, Spicer MT. Low-grade chronic inflammation perpetuated by modern diet as a promoter of obesity and osteoporosis. Arh Hig Rada Toksikol. 2014;65(2):139-148.

4. Inglis JE, Ilich JZ. The microbiome and osteosarcopenic obesity in older individuals in long-term care facilities. Curr Osteoporos Rep. 2015;13(5):358-362.

5. Administration for Community Living [webpage on the Internet]. Aging Statistics. Available from: http://www.aoa.acl.gov/Aging_Statistics/ index.aspx. Accessed January 1, 2016.

6. NIH Consensus Statement. Osteoporosis Prevention, Diagnosis, and Therapy. 2000;17(1):1-45. Available from: https://consensus.nih. gov/2000/2000Osteoporosis111PDF.pdf. Accessed November 29, 2016.

7. Kim K, Yun SH, Jang MJ, Oh KW. Body fat percentile curves for Korean children and adolescents: a data from the Korea National Health and Nutrition Examination Survey 2009-2010. J Korean Med Sci. 2013;28(3):443.

8. Brownbill RA, Ilich JZ. Measuring body composition in overweight individuals by dual energy x-ray absorptiometry. BMC Med Imaging. 2005;5(1):1.

9. Newman AB, Kupelian V, Visser M, et al; Health ABC Study Investigators. Sarcopenia: alternative definitions and associations with lower extremity function. $J$ Am Geriatr Soc. 2003;51(11):1602-1609.

10. Baumgartner RN, Waters DL, Gallagher D, Morley JE, Garry PJ. Predictors of skeletal muscle mass in elderly men and women. Mech Ageing Dev. 1999;107(2):123-136.

11. Ilich JZ, Inglis JE, Kelly OJ, McGee DL. Osteosarcopenic obesity is associated with reduced handgrip strength, walking abilities, and balance in postmenopausal women. Osteoporos Int. 2015;26(11):2587-2595.
12. Pahor M, Manini T, Cesari M. Sarcopenia: clinical evaluation, biological markers and other evaluation tools. J Nutr Health Aging. 2009; 13(8):724-728.

13. Hanrahan CJ, Shah LM. MRI of spinal bone marrow: part 2, T1-weighted imaging-based differential diagnosis. AJR Am J Roentgenol. 2011; 197(6):1309-1321.

14. Liu Y, Tang G, Tang R, Peng Y, Li W. Assessment of bone marrow changes in postmenopausal women with varying bone densities: magnetic resonance spectroscopy and diffusion magnetic resonance imaging. Chin Med J (Engl). 2010;123(12):1524-1527.

15. Ace FitAce Fitness [webpage on the Internet]. What are the guidelines for percentage of body fat loss? 2009. Available from: https:// www.acefitness.org/acefit/healthy-living-article/60/112/what-are-theguidelines-for-percentage-of-body-fat. Accessed January 1, 2016.

16. JafariNasabian P. Analyzing Bone, Muscle and Adipose Tissue Biomarkers to Identify Osteosarcopenic Obesity Syndrome in Older Women [dissertation]. In press 2017.

17. Castro JP, Joseph LA, Shin JJ, et al. Differential effect of obesity on bone mineral density in White, Hispanic and African American women: a cross sectional study. Nutr Metab (Lond). 2005;2(1):9.

18. Travison TG, Araujo AB, Esche GR, McKinlay JB. The relationship between body composition and bone mineral content: threshold effects in a racially and ethnically diverse group of men. Osteoporos Int. 2008; 19(1):29-38.

19. Cao JJ, Picklo MJ. Involuntary wheel running improves but does not fully reverse the deterioration of bone structure of obese rats despite decreasing adiposity. Calcif Tissue Int. 2015;97(2):145-155.

20. Douchi T, Yamamoto S, Oki T, et al. Difference in the effect of adiposity on bone density between pre- and postmenopausal women. Maturitas. 2000;34(3):261-266.

21. Berg RM, Wallaschofski H, Nauck M, et al. Positive association between adipose tissue and bone stiffness. Calcif Tissue Int. 2015;97(1):40-49.

22. Wellen KE, Hotamisligil GS. Inflammation, stress, and diabetes. JClin Invest. 2005;115(5):1111-1119.

23. JafariNasabian P, Chi Y-C, Ilich JZ. Adipokines as mediators of bone density in overweight/obese postmenopausal women after 6-month weight loss program. FASEB J. 2015;29(1):738.4.

24. Deshpande S, James AW, Blough J, et al. Reconciling the effects of inflammatory cytokines on mesenchymal cell osteogenic differentiation. J Surg Res. 2013;185(1):278-285.

25. Gimble JM, Zvonic S, Floyd ZE, Kassem M, Nuttall ME. Playing with bone and fat. J Cell Biochem. 2006;98(2):251-266.

26. Rosen CJ, Bouxsein ML. Mechanisms of disease: is osteoporosis the obesity of bone? Nat Clin Pract Rheumatol. 2006;2(1):35-43.

27. Dodds RA, Merry K, Littlewood A, Gowen M. Expression of mRNA for IL1 beta, IL 6 and TGF beta 1 in developing human bone and cartilage. J Histochem Cytochem. 1994;42(6):733-744.

28. Krisher T, Bar-Shavit Z. Regulation of osteoclastogenesis by integrated signals from toll-like receptors. J Cell Biochem. 2014;115(12): 2146-2154.

29. Canavan B, Salem RO, Schurgin S, et al. Effects of physiological leptin administration on markers of inflammation, platelet activation, and platelet aggregation during caloric deprivation. J Clin Endocrinol Metab. 2005;90(10):5779-5785.

30. Ouchi N, Kihara S, Arita Y, et al. Adiponectin, an adipocyte-derived plasma protein, inhibits endothelial NF-kappaB signaling through a cAMP-dependent pathway. Circulation. 2000;102(11):1296-1301.

31. Scott D, Daly RM, Sanders KM, Ebeling PR. Fall and fracture risk in sarcopenia and dynapenia with and without obesity: the role of lifestyle interventions. Curr Osteoporos Rep. 2015;13(4):235-244.

32. Liu P-Y, Ilich JZ, Brummel-Smith K, Ghosh S. New insight into fat, muscle and bone relationship in women: determining the threshold at which body fat assumes negative relationship with bone mineral density. Int J Prev Med. 2014;5(11):1452-1463.

33. Rondanelli M, Guido D, Opizzi A, Faliva MA, Perna S, Grassi M. A path model of sarcopenia on bone mass loss in elderly subjects. J Nutr Health Aging. 2014;18(1):15-21. 
34. Shin H, Liu P-Y, Panton LB, Ilich JZ. Physical performance in relation to body composition and bone mineral density in healthy, overweight, and obese postmenopausal women. J Geriatr Phys Ther. 2014;37(1):7-16.

35. Hita-Contreras F, Martínez-Amat A, Cruz-Díaz D, Pérez-López FR. Osteosarcopenic obesity and fall prevention strategies. Maturitas. 2015; 80(2):126-132.

36. Sànchez-Riera L, Carnahan E, Vos T, et al. The global burden attributable to low bone mineral density. Ann Rheum Dis. 2014;73(9):1635-1645.

37. National Osteoporosis Foundation. National Osteoporosis Foundation Prevalence Report; 2014. Available from: https://www.nof.org/ about-us/nof-background/. Accessed February 9, 2014.

38. Rosenberg IH. Sarcopenia: origins and clinical relevance. J Nutr. 1997; 127(5 suppl):990S-991S.

39. Janssen I, Baumgartner RN, Ross R, Rosenberg IH, Roubenoff R. Skeletal muscle cutpoints associated with elevated physical disability risk in older men and women. Am J Epidemiol. 2004;159(4): 413-421.

40. Rolland Y, Abellan van Kan G, Gillette-Guyonnet S, Vellas B. Cachexia versus sarcopenia. Curr Opin Clin Nutr Metab Care. 2011;14(1): $15-21$.

41. Cruz-Jentoft AJ, Baeyens JP, Bauer JM, et al; European Working Group on Sarcopenia in Older People. Sarcopenia: European consensus on definition and diagnosis: report of the European Working Group on Sarcopenia in Older People. Age Ageing. 2010;39(4):412-423.

42. Colditz GA. Economic costs of obesity and inactivity. Med Sci Sports Exerc. 1999;31(11 suppl):S663-S667.

43. Cawley J, Meyerhoefer C. The medical care costs of obesity: an instrumental variables approach. J Health Econ. 2012;31(1):219-230.

44. Reilly JJ, Kelly J. Long-term impact of overweight and obesity in childhood and adolescence on morbidity and premature mortality in adulthood: systematic review. Int J Obes (Lond). 2011;35(7):891-898.

45. LeBlanc E, O'Connor E, Whitlock EP, Patnode C, Kapka T. Screening for and management of obesity and overweight in adults. Evid Synth. 2011;11-05159-EF-1.

46. Specchia ML, Veneziano MA, Cadeddu C, et al. Economic impact of adult obesity on health systems: a systematic review. Eur J Public Health. 2015;25(2):255-262.

47. Feinberg L, Reinhard SC, Houser A, Choula R. Valuing the Invaluable: 2011 Update - The Growing Contributions and Costs of Family Caregiving. AARP Public Policy Inst. Available from: http://assets.aarp.org/ rgcenter/ppi/ltc/i51-caregiving.pdf. Accessed November 29, 2016.

48. Osteoporosis/Bone Health in Adults as a National Public Health Priority. Available from: http://newsroom.aaos.org/media-resources/ Press-releases/american-academy-of-orthopaedic-surgeons-releasesnew-guidelines-on-hip-fractures-in-older-adults-acl-injuries-andinfant-dysplasia-of-the-hip.htm. Accessed January 1, 2016.

49. Morley JE, Anker SD, von Haehling S. Prevalence, incidence, and clinical impact of sarcopenia: facts, numbers, and epidemiology-update 2014. J Cachexia Sarcopenia Muscle. 2014;5(4):253-259.

50. Diz JBM, de Queiroz BZ, Tavares LB, et al. Prevalence of sarcopenia among the elderly: findings from broad cross-sectional studies in a range of countries. Rev Bras Geriatr e Gerontol. 2015;18(3):665-678.

51. Domiciano DS, Figueiredo CP, Lopes JB, et al. Discriminating sarcopenia in community-dwelling older women with high frequency of overweight/obesity: the São Paulo Ageing \& Health Study (SPAH). Osteoporos Int. 2013;24(2):595-603.

52. Zhu K, Hunter M, James A, Lim EM, Cooke BR, Walsh JP. Discordance between fat mass index and body mass index is associated with reduced bone mineral density in women but not in men: the Busselton Healthy Ageing Study. Osteoporos Int. Epub 2016 Jul 29.

53. Stefanaki C, Peppa M, Boschiero D, Chrousos GP. Healthy overweight/ obese youth: early osteosarcopenic obesity features. Eur J Clin Invest. 2016;46(9):767-778.

54. Goisser S, Kemmler W, Porzel S, et al. Sarcopenic obesity and complex interventions with nutrition and exercise in community-dwelling older persons - a narrative review. Clin Interv Aging. 2015;10:1267-1282.
55. Ogden CL, Carroll MD, Kit BK, Flegal KM. Prevalence of obesity among adults: United States, 2011-2012. NCHS Data Brief. 2013:1-8. Available from: http://www.ncbi.nlm.nih.gov/pubmed/24152742. Accessed December 16, 2016.

56. Flegal KM, Carroll MD, Kit BK, Ogden CL. Prevalence of obesity and trends in the distribution of body mass index among US adults, 1999-2010. JAMA. 2012;307(5):491-497.

57. Center for Disease Control and Prevention [webpage on the Internet]. Prevalence of obesity in the United States, 2009-2010. Available from: http://www.cdc.gov/nchs/data/databriefs/db82.htm\#Ref6. Accessed January 22, 2016.

58. Inglis JE, Panton LB, Ormsbee MJ, Kelly OJ, Ilich JZ [webpage on the Internet]. Defining osteosarcopenic obesity and identifying its prevalence in women across the age span. J Bone Miner Res. 2013. Available from: http://www.asbmr.org/education/AbstractDetail?aid=da7d06cc1551-4abf-8445-51dc6e53bcf7. Accessed January 11, 2017.

59. Inglis JE. Identifying Osteosarcopenic Obesity in a Group of Older Women [Dissertation]. In press 2017.

60. Kanis JA, Johnell O, Oden A, Dawson A, De Laet C, Jonsson B. Ten year probabilities of osteoporotic fractures according to BMD and diagnostic thresholds. Osteoporos Int. 2001;12(12):989-995.

61. Kelly OJ, Gilman JC, Kim Y, Ilich JZ. Macronutrient intake and distribution in the etiology, prevention and treatment of osteosarcopenic obesity. Curr Aging Sci. Epub 2016 May 9.

62. Kelly OJ, Gilman JC, Kim Y, Ilich JZ. Micronutrient intake in the etiology, prevention and treatment of osteosarcopenic obesity. Curr Aging Sci. Epub 2016 May 9.

63. Inglis JE, JafariNasabian P, Gilman JC, Kelly OJ, Ilich JZ. Possible nutritional etiology of osteosarcopenic obesity syndrome. FASEB J. 2016;30:1156.8.

64. Lattimer JM, Haub MD. Effects of dietary fiber and its components on metabolic health. Nutrients. 2010;2(12):1266-1289.

65. Price CT, Langford JR, Liporace FA. Essential nutrients for bone health and a review of their availability in the average North American Diet. Open Orthop J. 2012;6:143-149.

66. Pray L, Boon C, Ann Miller E, Pillsbury L [webpage on the Internet]. Providing Healthy and Safe Foods as We Age: Workshop Summary. Institude Med Natl Acad; 2010. Available from: http://www.nap.edu/ catalog/12967.html. Accessed October 16, 2016.

67. Ilich JZ, Brownbill RA. Habitual and low-impact activities are associated with better bone outcomes and lower body fat in older women. Calcif Tissue Int. 2008;83(4):260-271.

68. Zemel MB, Richards J, Milstead A, Campbell P. Effects of calcium and dairy on body composition and weight loss in African-American adults. Obes Res. 2005;13(7):1218-1225.

69. Morley JE. Anorexia, sarcopenia, and aging. Nutrition. 2001;17(7-8): 660-663.

70. Bales CW, Ritchie CS. Sarcopenia, weight loss, and nutritional frailty in the elderly. Annu Rev Nutr. 2002;22:309-323.

71. Campbell WW, Crim MC, Dallal GE, Young VR, Evans WJ. Increased protein requirements in elderly people: new data and retrospective reassessments. Am J Clin Nutr. 1994;60(4):501-509.

72. Churchward-Venne TA, Breen L, Phillips SM. Alterations in human muscle protein metabolism with aging: protein and exercise as countermeasures to offset sarcopenia. Biofactors. 2014;40(2):199-205.

73. Breen L, Phillips SM. Interactions between exercise and nutrition to prevent muscle waste during ageing. Br J Clin Pharmacol. 2013; 75(3):708-715.

74. Nowson C, O'Connell S. Protein requirements and recommendations for older people: a Review. Nutrients. 2015;7(8):6874-6899.

75. Campbell WW, Trappe TA, Wolfe RR, Evans WJ. The recommended dietary allowance for protein may not be adequate for older people to maintain skeletal muscle. J Gerontol A Biol Sci Med Sci. 2001;56(6): M373-M380.

76. Fitzmaurice D, Doyle L. The effect of a low-carbohydrate diet on biomarkers of bone health in pre- and post-menopausal females: a randomized control crossover trial. Proc Nutr Soc. 2011;70(OCE6):E355. 
77. Kelly OJ, Gilman JC, Kim Y, Ilich JZ. Long-chain polyunsaturated fatty acids may mutually benefit both obesity and osteoporosis. Nutr Res. 2013;33(7):521-533.

78. Booth FW, Gordon SE, Carlson CJ, Hamilton MT. Waging war on modern chronic diseases: primary prevention through exercise biology. J Appl Physiol. 2000;88(2):774-787.

79. Hughes VA, Frontera WR, Wood M, et al. Longitudinal muscle strength changes in older adults: influence of muscle mass, physical activity, and health. J Gerontol A Biol Sci Med Sci. 2001;56(5): B209-B217.

80. Kelly OJ, Gilman JC. Can unconventional exercise be helpful in the treatment, management and prevention of osteosarcopenic obesity? Curr Aging Sci. Epub 2016 May 9.

81. Deckx N, Wens I, Nuyts AH, et al. 12 weeks of combined endurance and resistance training reduces innate markers of inflammation in a randomized controlled clinical trial in patients with multiple sclerosis. Mediators Inflamm. 2016;2016:6789276.

82. Wolff I, van Croonenborg JJ, Kemper HC, Kostense PJ, Twisk JW. The effect of exercise training programs on bone mass: a meta-analysis of published controlled trials in pre- and postmenopausal women. Osteoporos Int. 1999;9(1):1-12.

83. Lanyon LE. Functional strain as a determinant for bone remodeling. Calcif Tissue Int. 1984;36(suppl 1):S56-S61.

84. Garber CE, Blissmer B, Deschenes MR, et al; American College of Sports Medicine. Quantity and quality of exercise for developing and maintaining cardiorespiratory, musculoskeletal, and neuromotor fitness in apparently healthy adults: guidance for prescribing exercise. Med Sci Sports Exerc. 2011;43(7):1334-1359.

85. Gillespie LD, Robertson MC, Gillespie WJ, et al. Interventions for preventing falls in older people living in the community. Cochrane Database Syst Rev. 2012;(2):CD007146.

86. Franco MR, Pereira LS, Ferreira PH. Exercise interventions for preventing falls in older people living in the community. Br J Sports Med. 2014;48(10):867-868.

87. Shapses SA, Sukumar D. Bone metabolism in obesity and weight loss. Annu Rev Nutr. 2012;32:287-309.

88. Chao D, Espeland MA, Farmer D, et al. Effect of voluntary weight loss on bone mineral density in older overweight women. J Am Geriatr Soc. 2000;48(7):753-759.

89. Compston JE, Laskey MA, Croucher PI, Coxon A, Kreitzman S. Effect of diet-induced weight loss on total body bone mass. Clin Sci (Lond). 1992;82(4):429-432.

90. Ensrud KE, Ewing SK, Stone KL, et al; Study of Osteoporotic Fractures Research Group. Intentional and unintentional weight loss increase bone loss and hip fracture risk in older women. J Am Geriatr Soc. 2003;51(12):1740-1747.

91. Pritchard JE, Nowson CA, Wark JD. Bone loss accompanying dietinduced or exercise-induced weight loss: a randomised controlled study. Int J Obes Relat Metab Disord. 1996;20(6):513-520.

92. Jensen LB, Kollerup G, Quaade F, Sørensen OH. Bone minerals changes in obese women during a moderate weight loss with and without calcium supplementation. J Bone Miner Res. 2001;16(1):141-147.

93. Little JP, Phillips SM. Resistance exercise and nutrition to counteract muscle wasting. Appl Physiol Nutr Metab. 2009;34(5):817-828.
94. Glover EI, Phillips SM. Resistance exercise and appropriate nutrition to counteract muscle wasting and promote muscle hypertrophy. Curr Opin Clin Nutr Metab Care. 2010;13(6):630-634.

95. Meng S-J, Yu L-J. Oxidative stress, molecular inflammation and sarcopenia. Int J Mol Sci. 2010;11(4):1509-1526.

96. Chung HY, Lee EK, Choi YJ, et al. Molecular inflammation as an underlying mechanism of the aging process and age-related diseases. $J$ Dent Res. 2011;90(7):830-840.

97. Kohrt WM, Bloomfield SA, Little KD, Nelson ME, Yingling VR; American College of Sports Medicine. American College of Sports Medicine Position Stand: physical activity and bone health. Med Sci Sports Exerc. 2004;36(11):1985-1996.

98. Kelley GA, Kelley KS, Tran ZV. Resistance training and bone mineral density in women: a meta-analysis of controlled trials. Am J Phys Med Rehabil. 2001;80(1):65-77.

99. Kemmler W, von Stengel S. Alternative exercise technologies to fight against sarcopenia at old age: a series of studies and review. J Aging Res. 2012;2012:109013.

100. Choices $\mathrm{N}$ [webpage on the Internet]. Physical activity guidelines for older adults - Live Well - NHS Choices. Available from: http://www. nhs.uk/Livewell/fitness/Pages/physical-activity-guidelines-for-olderadults.aspx. Accessed November 29, 2016.

101. Bastin S, Gamble GD, Grey A, Reid IR. Calcium Dietary Supplement Fact Sheet. Bethesda, MD: National Institute of Health, Office of Dietary Supplements 2016.

102. Magnesium Fact Sheet for Health Professionals [webpage on the Internet]. National Institute of Health, Office of Dietary Supplements. Available from: https://ods.od.nih.gov/factsheets/Magnesium-HealthProfessional/. Accessed December 16, 2016.

103. National Institute of Health, Office of Dietary Supplements [webpage on the Internet]. Vitamin D Fact Sheet for Health Professionals. Available from: https://ods.od.nih.gov/factsheets/VitaminD-HealthProfessional/. Accessed December 16, 2016.

104. National Institute on Aging [webpage on the Internet]. Falls and Fractures. Available from: https://www.nia.nih.gov/health/publication/ falls-and-fractures. Accessed December 16, 2016.

105. Aloia JF, Cohn SH, Ostuni JA, Cane R, Ellis K. Prevention of involutional bone loss by exercise. Ann Intern Med. 1978;89(3):356-358.

106. Pedersen BK. Muscle as a secretory organ. Compr Physiol. 2013;3(3): 1337-1362.

107. Rousset S, Patureau Mirand P, Brandolini M, Martin J-F, Boirie Y. Daily protein intakes and eating patterns in young and elderly French. Br J Nutr. 2003;90(6):1107-1115.

108. Symons TB, Sheffield-Moore M, Mamerow MM, Wolfe RR, PaddonJones D. The anabolic response to resistance exercise and a proteinrich meal is not diminished by age. J Nutr Health Aging. 2011;15(5): 376-381.

109. Jakicic JM. Exercise in the treatment of obesity. Endocrinol Metab Clin North Am. 2003;32(4):967-980.

110. Pitsavos C, Panagiotakos D, Weinem M, Stefanadis C. Diet, exercise and the metabolic syndrome. Rev Diabet Stud. 2006;3(3):118-126.

111. Coker RH, Williams RH, Kortebein PM, Sullivan DH, Evans WJ. Influence of exercise intensity on abdominal fat and adiponectin in elderly adults. Metab Syndr Relat Disord. 2009;7(4):363-368.
International Journal of Women's Health

\section{Publish your work in this journal}

The International Journal of Women's Health is an international, peerreviewed open-access journal publishing original research, reports, editorials, reviews and commentaries on all aspects of women's healthcare including gynecology, obstetrics, and breast cancer. The manuscript management system is completely online and includes

\section{Dovepress}

a very quick and fair peer-review system, which is all easy to use. Visit http://www.dovepress.com/testimonials.php to read real quotes from published authors. 